\title{
Comparison of the distribution of blood groups in inflammatory rheumatic diseases and healthy subjects
}

\section{İnflamatuar romatizmal hastalıklarda kan grupları dağılımının sağlıklı kontrollerle karşılaştırılması}

\author{
Ahmet Karada $\breve{g}$
}

Department of Physical Medicine and Rehabilitation, Faculty of Medicine, Sivas Cumhuriyet University, Sivas, Turkey

Corresponding author: Ahmet Karadağ, MD, Department of Physical Medicine and Rehabilitation, Faculty of Medicine, Sivas Cumhuriyet

University, Sivas, Turkey

E-mail: dr ahmetkaradag@hotmail.com

Received/ĀAccepted: July 07, 2019 /September 11, 2019

Conflict of interest: There is not a conflict of interest.

\section{SUMMARY}

Objective: The present study investigates whether a relationship exists between the $\mathrm{ABO}$ and $\mathrm{Rh}$ blood groups and the type of rheumatic disease in patients with inflammatory rheumatic disease.

Method: The present study was based on the data of 1,272 healthy subjects and 1,028 patients with an inflammatory rheumatic disease who were followed up in our clinic between June 2016 and January 2019. The type of rheumatic disease and the $\mathrm{ABO}$ and $\mathrm{Rh}$ blood groups of the participants were recorded.

Results: The A blood group was more prevalent in patients with inflammatory rheumatic disease and in the healthy subjects, followed by the $\mathrm{O}, \mathrm{B}$, and $\mathrm{AB}$ blood groups in respective order, although there was no significant difference between the ABO groups in terms of distribution $(\mathrm{p}>0.05)$. The $\mathrm{Rh}(+)$ blood group was more prevalent than $\mathrm{Rh}$ $(-)$ in both groups, although there was a statistically significant difference in terms of the distribution of the Rh blood group among the groups $(\mathrm{p}<0.05)$. According to the results of logistic regression analysis, the $\mathrm{Rh}(-)$ blood type decreases the likelihood of developing a rheumatic disease $(p<0.05)$.

Conclusions: The A and $\mathrm{Rh}(+)$ blood groups were more commonly observed in patients with inflammatory rheumatic diseases, followed by the $\mathrm{O}, \mathrm{B}$, and $\mathrm{AB}$ blood groups. Furthermore, patients with the Rh (-) blood type were less likely to develop rheumatic disease. The present study may serve as a guide for future clinical studies evaluating the relationship between rheumatic diseases and blood types in terms of genetic predisposition and pathogenesis.

Keywords: Rheumatic diseases, ABO blood groups, Rh factor
Ahmet Karadağ

ORCID IDs of the authors: A.K. 0000-0002-5284-2256

\section{ÖZET}


Bulgular: İnflamatuar romatizmal hastalıklarda ve sağlıklı bireylerde A kan grubu daha sık görülmekte olup A kan grubunu sırasıyla $\mathrm{O}, \mathrm{B}, \mathrm{AB}$ kan grupları takip etmekteydi ve gruplar arasında $\mathrm{ABO}$ kan grubu dağılımı açısından istatiksel olarak fark yoktu ( $>0.05)$. Her iki grupta $\mathrm{Rh}+$ kan grubu daha sık görülmekteydi fakat gruplar arasında Rh kan grubu dağılımı açısından istatiksel olarak anlamlı fark vardı $(\mathrm{p}<0.05)$. Lojistik regresyon analizi sonuçlarına göre, $\mathrm{Rh}(-)$ kan grubu romatizmal bir hastalık geliştirme olasılığını azaltır $(\mathrm{p}<0.05)$.

Sonuç: İnflamatuar romatizmal hastalıklarda A ve $\mathrm{Rh}+$ kan grubu daha sık görülmektedir ve A kan grubunu sırasıyla O, B, AB kan grupları takip etmektedir. Ayrıca, Rh (-) kan grubu olan bireylerde romatizmal hastalık gelişme olasılığı daha düşüktü. Bu çalışmanın sonuçları romatizmal hastalıklar ve kan tipleri arasındaki ilişkiyi genetik yatkınlık ve patogenez açısından değerlendirecek klinik çalışmalara rehberlik edebilir.

Anahtar sözcükler: Romatizmal hastalıklar, ABO kan grupları, Rh faktör

\section{INTRODUCTION}

Inflammatory rheumatic diseases are a group of systemic disorders with a chronic course and with an unknown etiopathogenesis. Recent studies have implicated environmental factors and genetic background in the etiology of inflammatory rheumatic diseases. ${ }^{1,2}$ The $\mathrm{ABO}$ blood type system was described many years ago ${ }^{3}$, and there are four main blood types depending on the presence of $\mathrm{A}$ and $\mathrm{B}$ antigens: $\mathrm{A}, \mathrm{B}, \mathrm{AB}$ and $\mathrm{O} .{ }^{4}$ In the Rhesus system, blood is classified as either $\mathrm{Rh}(-)$ or $\mathrm{Rh}(+)$ according to the presence of Rhesus $\mathrm{D}$ antigen on the surface of the red blood cells. ${ }^{5}$ The ABO and $\mathrm{Rh}$ blood groups are used in clinical practice, although numerous other blood groups have been identified related to the presence of different antigens. The frequency of distribution of the ABO and $\mathrm{Rh}$ blood groups varies between races. $\mathrm{O}$ blood group is more common around the world ${ }^{6}$, although studies have reported higher frequency rates of the $\mathrm{A}$ and $\mathrm{Rh}(+)$ blood groups in Turkey. ${ }^{7,8} \mathrm{ABO}$ antigens are complex carbohydrate molecules that are expressed on the surfaces of red blood cells, but also on the epithelium, neurons, platelets, and vascular endothelial cells. ${ }^{9,10}$ The ABO gene system, therefore, controls a certain proportion of the carbohydrate repertoire. ${ }^{11,12}$ These carbohydrates possess a variable structural diversity, but also act as a potential receptor for the pathogenic and nonpathogenic microorganisms that are involved in infections and susceptibility to, or resistance against, diseases. ${ }^{12,13}$ This raises the possibility that $\mathrm{ABO}$ antigens may play a role in the pathogenesis of various diseases. Previous studies have demonstrated a possible link between the $\mathrm{ABO}$ and $\mathrm{Rh}$ blood groups and such diseases as diabetes, cancer, cardiovascular disease and infection. ${ }^{14-16}$ It has been asserted that the ABO antigen system plays a role in the pathogenesis of these disorders through the Von Willebrand factor and various proinflammatory and adhesion molecules. ${ }^{17,18}$ Similarly, proinflammatory cytokines and adhesion molecules, together with genetic background, have been implicated in the pathogenesis of rheumatic diseases. ${ }^{19-21}$ Due to the involvement of similar mechanisms in the pathogenesis, the authors suggest that a relationship may exist between the $\mathrm{ABO}$ antigen system and rheumatic disease, although there have been only a limited number of studies in the literature evaluating the relationship between inflammatory rheumatic disease and blood types. This relationship continues to be poorly understood due to the lack of a control group in studies reported in literature, and to the best of our knowledge, there has been no study conducted to date on Turkish patients comparing the distribution of blood types in patients with inflammatory rheumatic diseases with that of healthy controls. The aim of the present study is, therefore, to compare the distribution of $\mathrm{ABO}$ and $\mathrm{Rh}$ blood types between patients with various inflammatory rheumatic diseases with that of healthy controls.

\section{MATERIAL AND METHODS}

The present study evaluated retrospectively the records of 1500 patients who were followed up at our clinic due to inflammatory rheumatic disease (rheumatoid arthritis [RA], spondyloarthropathy [SpA], Behçet's diseases [BD],vasculitis, undifferentiated connective tissue disease [UCTD], familial Mediterranean fever [FMF], systemic sclerosis [SSc], polymyositis- dermatomyositis [PM-DM], systemic lupus erythematosus [SLE], Sjögren's syndrome $[\mathrm{SjS}]$ and gout) between June 2016 and January 2019, and of whom blood groups were available (Group 1), and those of 1272 healthy blood donors (Group 2). The past medical histories of the patients with inflammatory rheumatic disease to be included in the study were reviewed, and aside from inflammatory rheumatic disease, patients with autoimmune, inflammatory, endocrine, gastrointestinal and hematological disorders, and patients with cancer, chronic infection and cardiovascular disease that were previously evaluated for their relationship with the blood types were excluded from the study. The 
gender, type of rheumatic disease, and ABO and $\mathrm{Rh}$ blood groups of the participants were recorded.

The study was approved by the Human Ethics Committee of our University and was conducted in accordance with the principles of the Declaration of Helsinki. Informed consent was obtained from all individual participants included in the study.

\section{Statistical analyses}

Analyses were conducted with the IBM SPSS Statistics 22 (IBM Corp., Armonk, NY, USA). The data are presented as percentages. A Chi-Square test was used to evaluate the categorical data. In logistic regression analysis, the gender, $\mathrm{ABO}$ and $\mathrm{Rh}$ blood group data entered into the model. A pvalue of $<0.05$ was considered statistically significant.

\section{RESULTS}

The study was conducted on the data of 1272 healthy subjects and 1028 patients with an inflammatory rheumatic disease who met the study inclusion criteria (Diagram 1). Group 1 comprised $395(38.4 \%)$ males and $633(61.6 \%)$ females, and Group 2 comprised 1198 (94.2\%) males and 74 $(5.8 \%)$ females. Gender distribution was not homogeneous between the groups $(\mathrm{p}<0.05)$. Distribution of the ABO blood type was similar between the two groups. However, the $\mathrm{Rh}(+)$ blood type was more prevalent in patients with rheumatic disease when compared to the healthy control group, and the difference was statistically significant $(p<0.05)$. The distribution of the ABO and $\mathrm{Rh}$ blood types in the two groups are presented in Table 1. When the present rheumatic diseases were evaluated in terms of the distribution of $\mathrm{ABO}$ blood groups, the $\mathrm{A}$ and $\mathrm{O}$ blood groups were equally distributed among patients with SLE, the O blood group was more prevalent in patients with gout, whereas the A blood group was more prevalent in patients with other inflammatory rheumatic diseases, although the findings in this regard were not statistically significant $(\mathrm{p}>0.05)$ (Table 2). When rheumatic diseases were evaluated in terms of the distribution of the Rh blood group, $\mathrm{Rh}(+)$ was more prevalent in all rheumatic diseases, although there was no significant difference between the groups of rheumatic diseases in terms of $\mathrm{Rh}$ blood group distribution $(\mathrm{p}>0.05)$ (Table 3). According to the results of logistic regression analysis, the $\mathrm{Rh}(-)$ blood type decreases the likelihood of developing a rheumatic disease $(p<0.05)$ (Table 4).

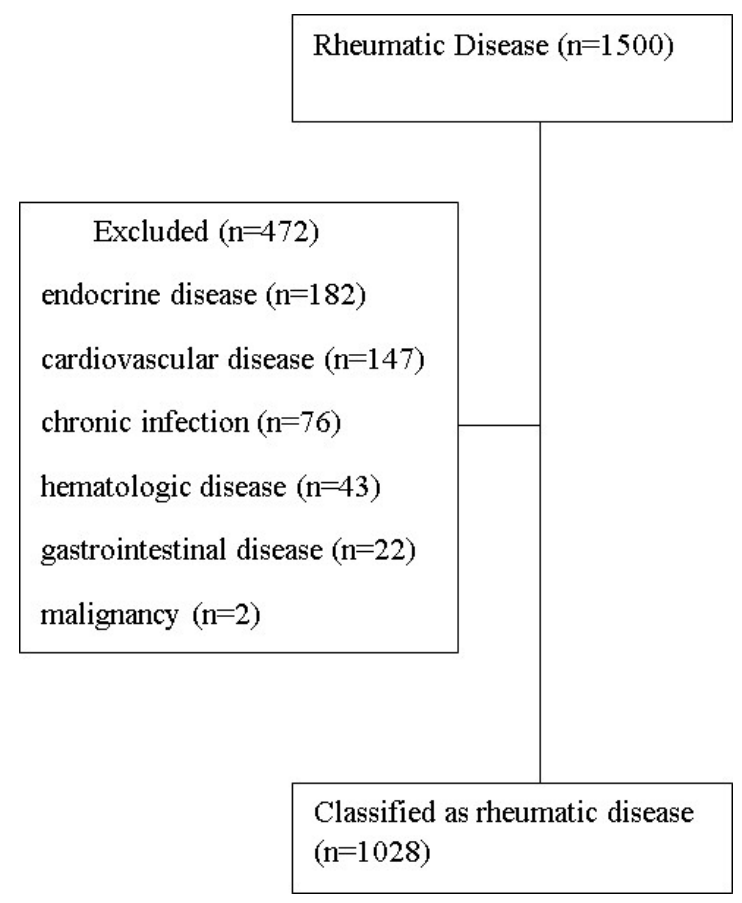

Diagram 1: Flow diagram of the selection process for the patient groups 
Table 1: Distribution of $\mathrm{ABO}$ and $\mathrm{Rh}$ blood groups in the two groups

\begin{tabular}{|lccl|}
\hline & Rheumatic Disease & Healthy Control & \\
\hline & $\mathrm{n}(\%)$ & $\mathrm{n}(\%)$ & Significance \\
B & $462(44.9)$ & $561(44.1)$ & \\
O & $162(15.8)$ & $168(13.2)$ & \\
AB & $314(30.5)$ & $406(31.9)$ & $\begin{array}{l}\mathrm{x}^{2}=5.35 \\
\mathrm{df}=3\end{array}$ \\
$\mathrm{p}=0.148$
\end{tabular}

Rh: Rhesus

Table 2: Distribution of ABO blood group in patients with rheumatic diseases

\begin{tabular}{|c|c|c|c|c|c|c|}
\hline & A & $\mathrm{B}$ & $\mathrm{O}$ & $\mathrm{AB}$ & Total & \\
\hline & $\mathrm{n}(\%)$ & $\mathrm{n}(\%)$ & $\mathrm{n}(\%)$ & $\mathrm{n}(\%)$ & $\mathrm{n}(\%)$ & Significance \\
\hline RA & $218(42.5)$ & $73(14.3)$ & $181(35.2)$ & $41(8)$ & $513(100)$ & \\
\hline $\mathrm{SpA}$ & $85(49.7)$ & $30(17.6)$ & $42(24.5)$ & $14(8.2)$ & $171(100)$ & \\
\hline $\mathrm{BD}$ & $28(51.9)$ & $8(14.8)$ & $13(24.1)$ & $5(9.2)$ & $54(100)$ & \\
\hline FMF & $28(53.9)$ & $8(15.3)$ & $12(23.1)$ & $4(7.7)$ & $52(100)$ & $x 2=28.1$ \\
\hline SLE & $16(31.4)$ & $12(23.5)$ & $16(31.4)$ & $7(13.7)$ & $51(100)$ & $\mathrm{df}=30$ \\
\hline MCTD & $23(47.9)$ & $9(18.7)$ & $13(27.2)$ & $3(6.2)$ & $48(100)$ & $\mathrm{p}=0.565$ \\
\hline $\mathrm{PM} / \mathrm{DM}$ & $20(54)$ & $6(16.2)$ & $8(21.6)$ & $3(8.2)$ & $37(100)$ & \\
\hline $\mathrm{SSc}$ & $12(41.4)$ & $7(24.1)$ & $7(24.1)$ & $3(10.4)$ & $29(100)$ & \\
\hline $\mathrm{SjS}$ & $12(48)$ & $3(12)$ & $7(28)$ & $3(12)$ & $25(100)$ & \\
\hline Gout & $9(36)$ & $3(12)$ & 11(44) & $2(8)$ & $25(100)$ & \\
\hline Vasculitis & $12(52.2)$ & $3(13)$ & $5(21.8)$ & $3(13)$ & $23(100)$ & \\
\hline
\end{tabular}

RA; Rheumatoid arthritis, SpA; Spondyloarthropathy, BD; Behçet's diseases, UCTD; Undifferentiated connective tissue disease, FMF; Familial Mediterranean Fever, SLE; Systemic lupus erythematosus, SSc; Systemic sclerosis, PM/DM; Polymyositis/Dermatomyositis, SjS; Sjögren's syndrome 
Table 3: Distribution of Rh blood group in patients with rheumatic diseases

\begin{tabular}{|lllll|}
\hline & $\mathrm{Rh}+$ & $\mathrm{Rh}-$ & Total & \\
\hline & $\mathrm{n}(\%)$ & $\mathrm{n}(\%)$ & $\mathrm{n}(\%)$ & Significance \\
RA & $457(89.1)$ & $56(10.9)$ & $513(100)$ & \\
SpA & $153(89.5)$ & $18(10.5)$ & $171(100)$ & \\
BD & $45(83.3)$ & $9(16.7)$ & $54(100)$ & \\
FMF & $42(80.8)$ & $10(19.2)$ & $52(100)$ & $\mathrm{x}^{2}=9.93$ \\
SLE & $46(90.2)$ & $5(9.8)$ & $51(100)$ & $\mathrm{df}=10$ \\
MCTD & $40(83.3)$ & $8(16.7)$ & $48(100)$ & $\mathrm{p}=0.446$ \\
PM/DM & $31(83.8)$ & $6(16.2)$ & $37(100)$ & \\
SSc & $23(79.3)$ & $6(20.7)$ & $29(100)$ & \\
SjS & $21(84)$ & $4(16)$ & $25(100)$ & \\
Gout & $22(88)$ & $3(12)$ & $25(100)$ & \\
Vasculitis & $22(95.7)$ & $1(4.3)$ & $23(100)$ & \\
\hline
\end{tabular}

RA; Rheumatoid arthritis, SpA; Spondyloarthropathy, BD; Behçet's diseases, UCTD; Undifferentiated connective tissue disease, FMF; Familial Mediterranean Fever, SLE; Systemic lupus erythematosus, SSc; Systemic sclerosis, PM/DM; Polymyositis/Dermatomyositis, SjS; Sjögren's syndrome

Table 4: Logistic regression analysis for the gender and the ABO and $\mathrm{Rh}$ blood types for the groups

\begin{tabular}{|c|l|c|c|c|c|}
\hline \multicolumn{2}{|c|}{ Logistic Regression } & Model 1 & Model 2 & Model 3 & Model 4 \\
\hline \multirow{2}{*}{$\begin{array}{c}\text { Independent } \\
\text { Variables } \\
\text { Coefficients }\end{array}$} & Gender & 2.245 & - & 2.005 & 1.005 \\
\cline { 2 - 6 } & ABO & -0.346 & $0.015^{*}$ & - & -0.602 \\
\cline { 2 - 6 } & $\mathrm{Rh}$ & -2.005 & -0.243 & -2.350 & - \\
\hline \hline \multirow{3}{*}{$\begin{array}{c}\text { Model } \\
\text { Statistics }\end{array}$} & Cox \& Snell & 0.264 & 0.018 & 0.243 & 0.127 \\
\cline { 2 - 6 } & Nagelkerke & 0.353 & 0.023 & 0.324 & 0.17 \\
\cline { 2 - 6 } & $\mathrm{p}$ & $<0.001$ & $<0.001$ & $<0.001$ & $<0.001$ \\
\hline
\end{tabular}

*The ABO variable in Model 2 is not significant. The gender and $\mathrm{Rh}$ variables are significant in all models, although gender distribution is not homogeneous between the groups. Accordingly, the $\mathrm{Rh}$ variable can be said to play a role in the development of the rheumatic disease.

\section{DISCUSSION}

The present study found that the A and $\mathrm{Rh}(+)$ blood groups were more prevalent in patients with inflammatory rheumatic disease and the A blood group was followed by $\mathrm{O}, \mathrm{B}$, and $\mathrm{AB}$ blood groups, in respective order. However the present study found that the distribution of $\mathrm{ABO}$ blood groups in patients with inflammatory rheumatic disease was no different to that of the healthy controls, although the $\mathrm{Rh}(+)$ blood group was more prevalent in patients with inflammatory rheumatic disease than in the healthy controls. In addition, the present study also found that individuals with $\mathrm{Rh}(-)$ blood type are less likely to develop a rheumatic disease. 
To our knowledge the present study is the first in the literature to report such findings.

Genetic factors may play a role in the development and prognosis of certain diseases. Blood groups are inherited and are not affected by environmental factors. ${ }^{3}$ Blood groups have been evaluated as hematological markers in various studies, and clinical studies have demonstrated a relationship between the $\mathrm{ABO}$ and $\mathrm{Rh}$ blood groups and various types of cancer, diabetes, and cardiovascular diseases. ${ }^{4,17,22}$ Although this has not been clarified, it is suggested that different mechanisms may be involved in the role played by $\mathrm{ABO}$ antigens in the pathogenesis of these diseases..$^{17,18,23}$ Previous clinical studies have shown that various genetic and environmental factors play a role in the etiology of inflammatory rheumatic disease. ${ }^{1,24,25}$ HLA genes, in particular, have been implicated in the pathogenesis of several rheumatic diseases (i.e. HLA-DRB1 and HLA-DP1 in RA, HLA-B27 in $\mathrm{SpA}$, and HLA-B51 in $\mathrm{BH}^{26-28}$ On the other hand, there are studies in literature identifying a possible relationship between HLA and ABO antigens. ${ }^{29,30}$ There are a limited number of studies in literature evaluating the distribution of blood types in patients with rheumatic disease, and the results of the few studies that do exist are variable. Stoia et al. ${ }^{31}$ reported that the A blood type is more prevalent in a study involving patients with RA and AS. Another study, conducted by Shinebaum ${ }^{32}$, reported a higher prevalence rate of the $\mathrm{O}$ blood type among patients with $\mathrm{SpA}$, while a further study reported a higher prevalence rate of the A blood type in patients with discoid lupus erythematosus. ${ }^{33}$ Ozyurt et al. ${ }^{34}$ identified a higher rate of $\mathrm{O}$ and $\mathrm{Rh}(+)$ blood types in patients with $\mathrm{BD}$. In a recent study involving no control group, $\mathrm{A}$ and $\mathrm{Rh}(+)$ blood types were found to be more prevalent among patients with RA, SpA, BD, UCTD and vasculitis, whereas $\mathrm{O}$ and $\mathrm{Rh}(-)$ blood types were found to be more common in patients with SLE, SSc and SjS. ${ }^{24}$ The present study found the $\mathrm{A}$ and $\mathrm{Rh}(+)$ blood types to be generally more prevalent in patients with inflammatory rheumatic disease. Previous studies have reported both similar and opposing results, ad similarly, the present study reports similar and opposing results compared to those reported in previous studies. The prevalence rates of blood types differ across nations, races, and regions. ${ }^{36}$ The differences between the results of the present study and those of previous studies may be attributed to the differences in the genetic basis of inflammatory rheumatic diseases.

One limitation of the present study that it was not conducted on a large patient population, that no genetic analysis was made of the patients, that the patient and control groups included in the study were from a single-center and gender distribution was not homogeneous between the groups.

In conclusion, the $\mathrm{A}$ and $\mathrm{Rh}(+)$ blood types were more commonly observed in inflammatory rheumatic disease, followed by the $\mathrm{O}, \mathrm{B}$, and $\mathrm{AB}$ blood types. Furthermore, patients with the Rh (-) blood type were less likely to develop rheumatic disease. The present study may serve as a guide for future clinical studies evaluating the relationship between rheumatic diseases and blood types in terms of genetic predisposition and pathogenesis. Further multicenter clinical studies involving larger patient groups, and that evaluate the distribution of blood types and genetic analyses in patients with rheumatic diseases are required.

\section{REFERENCES}

1. Sparks Jeffrey A, Costenbader Karen H. Genetics, environment, and gene-environment interactions in the development of systemic rheumatic diseases. Rheum Dis Clin North Am. 2014;40:637-57.

2. Kato M, Yasuda S, Atsumi T. The role of genetics and epigenetics in rheumatic diseases: are they really a target to be aimed at? Rheumatol Int. 2018;38:1333-1338.

3. Landsteiner K. Zur Kenntnis der antifermentativen, lytischen ve agglutinierenden Wirkungen des Blutserumsund der Lymphe. Zentralbl Bakteriol. 1900;27:357-62.

4. Zhang BL, He N, Huang YB, Song FJ, Chen KX. ABO Blood Groups and Risk of Cancer: a Systematic Review and Meta-analysis. Asian Pac J Cancer Prev. 2014;15:4643-4650

5. Behra D, Joshi D. Distribution of ABO blood group and RH (D) factor in Western Rajasthan. J Med Res 2013;3:73-75

6. Lippi G, Gandini G, Salvagno GL, Skafidas S, Festa L, Danese E, et al. Influence of ABO blood group on sports performance. Ann Transl Med. 2017;5:255

7. Doğan E, Sevimligül G, Çelik C, Şencan M. Blood group distribution of donors and patients admitted to the Blood and Transfusion Center of Cumhuriyet University Hospital. CMJ 2015;37:2329.

8. Dilek İ, Demir C, Bay A, Akdeniz H, Öner AF. $\mathrm{ABO}$ and $\mathrm{Rh}$ blood groups frequency in men and women living in eastern Turkey. UHOD 2006;1:23-6 
9. Franchini M, Liumbruno GM. ABO blood group: old dogma, new perspectives. Clin Chem Lab Med. 2013;51:1545-1553.

10. Liumbruno GM, Franchini M. Beyond immunohaematology: the role of the ABO blood group in human diseases. Blood Transfus. 2013;11:491-499.

11. Henry S.M. Molecular diversity in the biosynthesis of GI tract glycoconjugates. A blood group related chart microorganism receptors. Transfus Clin Biol. 2001;8:226-230.

12. Imberty A, Varrot A. Microbial recognition of human cell surface glycoconjugates. Curr Opin Struct Biol. 2008;18:567-576.

13. Maynard CL, Elson CO, Hatton RD., Weaver CT. Reciprocal interactions of the intestinal microbiota and immune system. Nature. 2012;489:231-241.

14. Gong P, Luo S, Li XL, Guo YL, Zhu CG, Xu $\mathrm{RX}$, et al. Relation of $\mathrm{ABO}$ blood groups to the severity of coronary atherosclerosis: An Gensini score assessment. Atherosclerosis 2014;237:748753

15. Senthil KV, Hwang J, Rostgaard K, Nyrén O, Ullum $\mathrm{H}$, Ole BV, et al. ABO blood group and risk of cancer: A register-based cohort study ofl.6 million blood donors. Cancer Epidemiology 2016;44:40-43.

16. Meo SA, Rouq F A, Suraya F, Za1dı SZ. Association of $\mathrm{ABO}$ and $\mathrm{Rh}$ blood groups with type 2 diabetes mellitus. Eur Rev Med Pharmacol Sci 2016; 20: 237-42.

17. Liumbruno GM, Franchini M. Hemostasis, cancer, and $\mathrm{ABO}$ blood group: the most recent evidence of association. J Thromb Thrombolysis. 2014;38:160-166.

18. Franchini M, Capra F, Targher G, Montagnana M, Lippi G. Relationship between ABO blood group and von Willebrand factor levels: from biology to clinical implications. Thromb J. 2007;5:14.

19. Yi YS. Role of inflammasomes in inflammatory autoimmune rheumatic diseases. Korean J Physiol Pharmacol. 2018;22:1-15.

20. Hjeltnes G, Hollan I, Førre O, Wiik A, Lyberg $\mathrm{T}$, Mikkelsen $\mathrm{K}$, et al. Serum levels of lipoprotein(a) and E-selectin are reduced in rheumatoid arthritis patients treated with methotrexate or methotrexate in combination with TNF- $\alpha$-inhibitor. Clin Exp Rheumatol. 2013;31:415-21.
21. McMurray RW. Adhesion molecules in autoimmune disease. Semin Arthritis Rheum. 1996;25:215-33.

22. He M, Wolpin B, Rexrode K, Manson JE, Rimm E, Hu FB, et al. ABO blood group and risk of coronary heart disease in two prospective cohort studies. Arterioscler Thromb Vasc Biol. 2012;32:2314-2320.

23. Barbalic M, Dupuis J, Dehghan A, Bis JC, Hoogeveen RC, Schnabel RB, et al. Large-scale genomic studies reveal central role of $\mathrm{ABO}$ insPselectin and sICAM-1levels. Hum Mol Genet. 2010;19:1863-1872.

24. Çildağ S, Kara Y, Şentürk T. ABO blood groups and rheumatic diseases. Eur J Rheumatol. 2017;4:250-253.

25. Van Steenbergen HW, Huizinga TW, van der Helm-van Mil AH. The preclinical phase of rheumatoid arthritis: what is acknowledged and what needs to be assessed? Arthritis Rheum. 2013;65:2219-32.

26. Okada Y, Wu D, Trynka G, Raj T, Terao C, Ikari $\mathrm{K}$, et al. Genetics of rheumatoid arthritis contributes to biology and drug discovery. Nature. 2014;506:376-81.

27. Reveille JD. Genetics of spondyloarthritis-beyond the MHC. Nat Rev Rheumatol. 2012;8:296-304.

28. Chambrun MP, Wechsler B, Geri G, Cacoub P, Saadoun D. New insights into the pathogenesis of Behçet's disease. Autoimmun Rev. 2012;11:68798.

29. Säljö K, Barone A, Mölne J, Rydberg L, Teneberg S, Breimer ME. HLA and Histo-Blood Group Antigen Expression in Human Pluripotent Stem Cells and their Derivatives. Sci Rep. 2017; 12:13072.

30. Dunbar NM, Yazer MH, Bravo MD, Kamel HT, Gorlin J, Norris PJ, et al. An association between ABO group and HLA antibody detection. Biomedical Excellence for Safer Transfusion (BEST) Collaborative. Transfusion. 2017;57:313318.

31. Stoia I, Ramneantu R, Poitas M. Blood groups $\mathrm{ABO}$ and $\mathrm{Rh}(\mathrm{D})$ factor in the rheumatic diseases. Ann Rheum Dis. 1967;26:332-3

32. Shinebaum R. ABO blood group and secretor status in the spondyloarthropathies. FEMS Microbiol Immunol. 1989;1(6-7):389-95 
33. Tamega AA, Pinto Bezerra LVGS, Pereira PP, Miot HA. Blood groups and discoid lupus erythematosus. An Bras Dermatol 2009; 84: 47781.

34. Özyurt K, Öztürk P, Gül M, Benderli YC, Çölgeçen E, Inci R. ABO blood groups, Rhesus factor, and Behçet's disease. Acta Dermatovenerol APA. 2013;22:63-64.

35. Donbak L, Rencuzogullari E, Topaktas M, Kayrin L. Detection of some blood group (ABO, RHD) and serum protein (HP, a1-AT, TF) polymorphisms in Antakya Province, Turkey. T Klin J Med Res 2002;20:109-13. 